\title{
К ВОПРОСУ О ПЕРЕСЕЛЕНИИ АЛБАНЦЕВ В БЕССАРАБИЮ В НАЧАЛЕ ХІХ В.
}

\author{
ИВАН ДУМИНИКА
}

\begin{abstract}
IX в. (The problem of resettlement of Albanians to Bessarabia at the beginning of the 19th century).

Balcanica Posnaniensia. Acta et studia, XX, Poznań 2013, Wydawnictwo Instytutu Historii UAM, pp. 95-103, ISBN 978-83-63047-36-1, ISSN 0239-4278. Russian text with a summary in English.

Иван Думиника, Великотырновский университет «Св.Св. Кирилл и Методий», Болгария.
\end{abstract}

Актуальность данной темы заключается в том, что на современном этапе в результате усиления этно-демографических и миграционных процессов в Восточной и Юго-Восточной Европе, порой меняется этническая составляющая определенной территории. Историческая наука становится важным проводником для государственных учреждений и научных институтов, которые занимаются изучением в области миграционных процессов происходивших в прошлом, для того, чтобы на современном этапе устанавливать более качественные условия для миграционных процессов и регулировать отношение между администрацией принимающего государства и этносами которые в результате политических и экономических причин были вынуждены эмигрировать в инородную этническую среду.

Объектом данной работы являются балканские переселенцы в нашем случае албанцы, которые в результате политических, экономических и социальных причин были вынуждены, переселиться на территории к северу от Дуная.

Исходя из актуальности исследуемой работы, её научной, политической и социальной значимости, главной целью будет детальный анализ роли русских и болгарских исследований в освящении проблемы переселения албанцев в Бессарабию.

Хронологические рамки для историографического исследования темы охватывают период начала появления первых упоминаний об албанских переселенцах в Бессарабии в начале XIX в. и так до новейшего времени - периода, когда продолжают публиковаться статьи и монографии по отдельным аспектам в области переселения балканских народов в Бессарабию. 
Теоретическая (методологическая) основа статьи является систематический подход, который ориентирует применительно к истории и на изучение в целостности сложного явления конкретной эпохи, понимания взаимообусловленности и взаимозависимости составных компонентов и рассмотрения его как части исторического процесса в исторической объективности. При провидении исследования использованы историко-сравнительный и проблемно-хронологический методbl.

В центре внимания исследователей XIX в. находились вопросы демографической и этнографической статистики. Значительное распространение получили этнографические описания населения Бессарабии. Данные книги не носили узкоспециализированный характер, а содержали разнообразные сведения, как по демографической статистике, так и об этническом описании населения Бессарабии.

Переселение албанцев в Бессарабию было составной частью переселения задунайских беженцев. По этой причине о прибытии албанцев на территорию Бессарабии в XIX в. мало упоминается в историографии данного периода, так как их рассматривали в контексте болгарских переселенцев и, тем более что переселение сюда данной группы население, происходило из территории Болгарии. В то же время, следует упомянуть то, что в статистических данных можно найти упоминания об «арнаутах» ${ }^{1}$, этнониме, который стал обозначать албанцев. В основном, краткие и отрывочные упоминания включались в общие труды описательного характера. При этом русские авторы, цель которых была показать покровительство царизма, не задавались вопросами о характере и условиях переселения столь малочисленной группы людей. Со своей стороны румынские авторы пытались показать переселенцев в Бессарабии, как людей, угнетенных царской властью.

Так одним из первых об албанских переселенцев упоминает болгарин Георгий Занетов в обширном труде «Болгарские колонии в России» указывая, что переселение албанцев к северу от Дуная началось ещё во время русско-турецкой войны 1787-1791 гг.». Автор отмечает, что в данный период в Россию из северо-восточной Болгарии проникают албанские семейства, которые впоследствии были заселены русскими властями в село Арнаутовка (сов. с. Александровка И. Д.) Одесского края ${ }^{2}$. Он же указывает, что уже в 1809-1810 гг. была отмечена вторая волна переселения, когда 300 семейств из болгарских сел Добрины, Староселец и в особенности из Девне переселились в Южную Россию 3.

\footnotetext{
${ }^{1}$ Турецкое название албанцев, переселившихся в Грецию в XIV - XVI вв. Это название в конце XVIII - начале XIX вв. закрепилось за албанцами и представителями других балканских народов, переселявшихся из Турецкой империи на земли, отвоеванные Российской империей у Турции в ходе российско-турецких войн второй половины XVIII в. (иногда в дореволюционной России арнаутами называли всех выходцев с Балканского полуострова) // Вокруг Света. 1865. С. 12.

2 Занетов Г., Българските колонии в Русия, Периодическо списание на българското книжовно дружество, IX, кн. XLVIII. Средец, 1895. С. 380.

${ }^{3}$ Там же. C. 871.
} 
В свою очередь, в русской историографии учёный, исследователь истории Украины и Бессарабии Аполлон Скальковский в обширном труде «Болгарские колонии в Бессарабии и в Новороссийском крае», первым начал сбор информации об этносах, проживающих в губерниях Южной России, пользуясь архивными фондами. И хотя его труд, не является подлинным научным исследованием, он представляет интерес в статистическом описании колоний. Так, им упоминается албанская колония Каракурт, которая: «была основана в 1811 г. на р. Сарлык вблизи старого татарского селища Каракурт» ${ }^{4}$. По его данным арнауты переселились сюда во время русско-турецкой войны 1808-1812 гг. из Европейской Турции, имея виду Болгарию, находившуюся под Османским владычеством. Им же указано число жителей албанцев «в количестве 1092 человека» ${ }^{5}$. Касаясь самого населения, А. Скальковский пишет, что жители отличаются трудолюбием, прекрасным хозяйством и особенною чистотою нравственности.

Подробно о данном этносе проживающем в данных краях Петр Кёппен - русский учёный немецкого происхождения, пишет буквально следующее: “Единственные в Болгарии арнауты, жившие в числе до 300 семейств в деревне Деви, близ Варны, в 1809 или 1810 году отправились чрез Галац в Бессарабию, где и были поселены в татарской деревне Чумае, что ныне хутор Чумай, на правой стороне р. Ялпуха, выше нынешней болгарской колонии Курчи и хутора Бурлачела, в бывшем Кагульском уезде. В 1820 году эти албанцы, или арнауты (шкипетары $\left.{ }^{6}\right),-$ из первоначального числа которых их немало вымерло, а некоторые, может быть, и возвратились в Болгарию, - наделены землею, вследствие указа 29 декабря 1819 года о даровании болгарам прав колониальных. С этого времени они постоянно живут на левой стороне озера Ялпуха, при речке Сарлык, в колонии Каракурт, в которой в 1850 году находилось 109 арнаутских семейств, состоящих из 1060 душ обоего пола. Во всей же Бессарабии находилось 154 семейства арнаутов с 686 мужского и 642 женского пола душами"7. Сведения исследователя являются важны, но в отличии от Георгия Занетова, Петр Кёппен не указывает, другие села, находившиеся поблизости как очаги исхода албанских беженцев, включая ошибочно их всех в одно село Девне.

Позднее, советский филолог-славист и историк Николай Державин в работе «Болгарские колонии в России», лишь укажет, что в 1826 г. в Южной Бессарабии насчитывалось 119 албанских хозяйств и 590 душ обоих полов, а к 1850 г. албанцев насчитывалось 1328 человек $^{8}$. Им же упоминается тот факт, что в 1862 г.

\footnotetext{
${ }^{4}$ Скальковскій А., Болгарскія колоніи в Бессарабіи и Новороссійскомъ крае. Статистическій очеркъ А. Скальковскаго. Въ Типографіи Т. Неймана и Ко. Одесса, 1848. С. 65.

5 Там же.

6 Так называют сами себя албанцы. (Шкиперия - туземное название Албании, от шкип - скала) // Энциколопедический словарь Брокгауза и Ефрона. Т. 39А (78) Спб. С. 483.

7 Кёппенъ П., Хронологическій указатель матеріаловъ для исторіи инородиевъ Европейской Россіи, Составленъ подъ руководствомъ П. Кёппенъ. Санкт-Петербург, тип. Имп. АН, 1861, VI, 1-2.

8 Державин Н. С., Болгарскія колоніи въ Россіи (Таврическая, Херсонская и Бессарабская губерніи), Матеріалы по славянской этнографіи. - СбНУ, кн. ХХІХ, София, 1914. С. 506.
} 
албанцы из Каракурта (сов. Жовтнево - И. Д.) переселились с тысячами болгар и гагаузов в южнорусскую область Таврию. Причиной этого он видит в том, что их территория перешла в результате Парижского договора 1856 г. во владение Молдавского княжества. Переселившись на новое место, они основали сёла Гамовка, Георгевка и Девненское (в честь своей исторической прародины) ${ }^{9}$.

В свою очередь, русский и советский зоолог и географ Лев Берг в труде, посвященном исследованию этнического состава и численности населения Бессарабии, отмечает, что селение Каракурт (с тур. черный червь или черный паук), основано в $1811 \Gamma^{10}$. Опираясь на статистическое описание Буджака автор определил, что: «съемка 1827 года застала их уже на нынешнем месте, в колонии Каракурт, где тогда было только 118 семейств арнаутов албанцев) общим числом 585 душ; кроме того здесь находилось 117 болгар» (т. е. гагаузов и болгар - И. Д.), 4 молдаван, 7 великорусов и 7 малорусов» ${ }^{11}$.

Что касается вопроса о прародине албанцев, большой интерес представляет данные чешского историка и путешественника Константина Иречека, посетившего Болгарию в конце XIX в. В обширном труде «История болгар», касаясь вопроса о переселении, он указывает народы которые со своим имуществом переселялись к север от Дуная, в числе которых упоминаются и албанцы ${ }^{12}$. В работе, которая в основном содержит хронологическую историю болгарского государства, автор не останавливается подробно о дальнейшей судьбе переселенцев. Лишь в следующей его работе «Путешествие по Болгарии» ${ }^{13}$ большой интерес представляет описания прародины бессарабских албанцев. Посетив село Девне, он пишет, что в данном селе живут албанцы-христиане, которые переселились сюда после завоевания их отечества турками. У него мы встречаем интересные данные, что в 1828 г. все албанцы данного села вместе с русскими войсками ушли в Бессарабию, где впоследствии ими было основана колония Каракурт ${ }^{14}$. Продолжая рассказ о дальнейшей судьбе албанцев, автор лишь упоминает, что по его данным потомки тех первых переселенцев уже забыли родной язык. И даже если и знают родной язык, то это старики, молодежь-же разговаривает на болгарском языке или на гагаузско-турецком наречии. В работе Константина Иречека интересен тот факт, что упоминается о втором массовом переселении албанцев, не упоминая о первом, которое произошло раньше, о котором мы отмечали в вышеизложенной работе болгарского исследователя Георгия Занетова.

\footnotetext{
9 Там же, С. 506-507.

${ }^{10}$ Берг Л.С., Население Бессарабии. Этнографический состав и численность, Петроград: Российская Гос. Акад. Тип. 1923. 1923. С. 29.

11 Берг Л.С., Население..., С. 29.

12 Иречек К., История на българите (с поправки и добавки от самия автор), Под. ред. на П. Петров. София: Изд. на ред. Научно списание. 1978. София, 1978. С. 561.

13 Иречек К., Пътувания по България. Превод от чешки Стоян Аргиров, Под редакцията на доц. Евлоги Бужашки и проф. Велизар Велков. Издателство Наука и изкуство, София, 1974. $1038 \mathrm{c}$.

14 Там же, С. 917.
} 
Так, тот же Г. Занетов пишет, что после Адрианопольского мира заключенном в 1829 г., всем желающим переселится, был дан восемнадцатимесячный срок на то, чтобы продать своё имущество, и переселится в любую выбранную ими христианскую страну. Что касается хода переселения, тот же автор упоминает, что этим воспользовались сто тысяч переселенцев из Болгарии, которые отправились в Валахию, Молдову и Бессарабию. Переселенцы же на протяжении всего пути были охраняемы русскими офицерами и казаками ${ }^{15}$.

Константин Иречек отмечает обратный процесс возвращения на прародину албанцев из Бессарабии в «результате природных невзгод» ${ }^{16}$. Он указывает на четыре семейства, возглавляемые Дукой Вэлювым вместе с двенадцатью семействами из села Чумлекиой которые заселились в «опустевшей Девне в Болгарии» ${ }^{17}$.

В молдавской историографии об албанцах в Бессарабии мы встречаем отрывочные данные у этнографа Валентина Зеленчука ${ }^{18}$. Автор ссылается на данные Петра Кёппена, упоминая о факте переселения в 1810 г. из болгарской деревни Девни, 300 семейств. Автор привносит новые данные отмечая то, что албанцы расселялись в селах Буджака: Чумай, Вулканенешты, Каракурт ${ }^{19}$.

Болгарский историк Атанас Ангелов в 2001 г. выпустил книгу об истории села Девня ${ }^{20}$. Автор уделяет отдельную главу процессу переселения албанского населения села Девня в Бессарабию. В работе он собирает отрывочные данные об албанцах, которые переселились в общей массе болгарского населения в Буджак. Причинами албанского переселения, по мнению автора, являются страх турецких репрессий, которые могли бы начаться после ухода русских войск в результате окончания русо - турецких войн 1806-1812 гг. и 1828-1829 гг. ${ }^{21}$

Вопрос о переселении албанцев в село Каракурт, частично затронут уроженцем данного села, Федором Дерментли в работе: «Перелистывая страницы памяти» ${ }^{22}$. Хотя его труд носит автобиографический характер, все же автор в главе, посвященной истории села знакомит нас с сохранившимися традициями, обычаями албанских переселенцев, опираясь на исторические документы. Федор Дерментли видит главнейшую причину переселения из села Девне - стремление албанцев спастись от турецкого ига, вторая не менее важная причина, которую затронул автор, это целенаправленная политика русского царизма по привлечению иностранных колонистов, занимавшихся у себя на прародине земледе-

15 Занетов Г., Българските колонии..., С. 878.

16 Иречек К., Пътувания..., С. 917.

17 Там же, С. 917 - 918.

18 Зеленчук В. С., Население Бессарабии и Поднестровья в ХІХ в.: Этнические и социальнодемографические процессы. Отв. ред. В. И. Козлов. Кищинёв: Штиинца, 1979. 288 с.

19 Там же, С. 228.

20 Ангелов А., Девня - страници от историята. Русе: Дунав прес АД, 2001. Второ издание Варна: LiterNet, 25.12.2003 < http://liternet.bg/publish10/aangelov/devnia/index.html> (27.03.2011).

21 Там же.

22 Дерментли Ф., Перелистывая страниць памяти. Донецк, 2004, 247c. 
лием, с целью освоения пустошных земель ${ }^{23}$. Опираясь на архивные данные г. Болграда (Украина), автор впервые указывает, что кроме колонии Каракурт, албанцы основали с. Кубей (сов. Червоноармейское), с. Ташбунар (сов. Каменка), с. Чийшия (сов. Огородное) и с. Чешмя - Варунта (сов. Криничное) $)^{24}$.

В 2004 г. выходит работа болгарского исследователя Бояна Гюзелева: «Албанците в източните Бълкани» ${ }^{25}$. В труде автор описывает историю появления албанцев на Балканском полуострове, включая их современную историю. Уделено внимание их заселению Болгарии, что привило к образовании нескольких сел, в том числе и с. Девня. Гюзелев указывает, что в 1810 г. меньшая часть жителей албанцев, живших в селах Добрина, Староселец, Девне переселилась в Россию ${ }^{26}$. Интересно то, что автор указывает на факт, что еще в XVIII в. албанцы католики с территории Сербской Воеводины проникают в Россию в количестве 500 человек ${ }^{27}$.

Болгарский исследователь преподносит совершенно новую информацию, упоминая о том, что албанцы в количестве 100 семейств, которые заложили основу колонии Каракурт, не были выходцами только из села Девне, по мнению автора, сюда следует добавить переселенцев из сел Добрина и Староселец.

Из вышеизложенного, мы приходим к выводу, что во-первых в историографии выделены несколько основных причин переселения албанцев в Бессарабию в начале XIX в. Из них мы можем указать такие как: 1) экономическая, для земледельцев коими были албанцы, не хватало земли, к тому же Российская империя наделяла каждое семейство, которое переселится в Бессарабию 60 десятинами земли плюс освобождение от налогов и наделением привилегий; 2) пропагандистская - показать османскому правительству, что их поданные в России живут достаточно хорошо, плюс участие албанцев-арнаутов в качестве волонтеров в русско-турецких войнах против Османской империи, серьезно подрывало ее репутацию на международной арене; 3) демографический бум в середине XVIII века в самой Албании, в результате чего Болгария стала первым местом оседлости перед дальнейшим продвижением в сторону Российских окраин; 4) боязнь репрессий со стороны османского правительства за сотрудничество с русскими войсками. Одним из основных болгарских пунктов исхода албанцев-переселенцев, кроме сел Добрина и Староселец, следует считать селение Девня, Провадийского уезда, которое находится недалеко от г. Варна.

На основе данных источников мы попытались сделать собственные выводы по поводу процесса заселения села Каракурт, которое стало местом, где устраиваются для поселения колонисты албанского происхождения ${ }^{28}$.

23 Там же, С. $20-21$.

24 Там же, С. 19.

25 Гюзелев Б., Албаниите в източните балкани. София, «Международен център за изследване на малцинствата и културните взаимодействия», 2004. 110 с.

${ }^{26}$ Там же, С. 95.

27 Там же.

${ }^{28}$ См. Приложение № 1. 
Приложение №1. Прибытие населения в албанскую колонию Каракурт.

\begin{tabular}{|l|c|c|c|}
\hline \multicolumn{1}{|c|}{ Годы } & Кол - во дворов & Мужчин & Женщин \\
\hline 1825 & 116 & $308 / 5$ дух. звания & $272 / 4$ дух. звания \\
1830 & 120 & 337 & 245 \\
Болг. Новоприб & 100 & 311 & 247 \\
$\mathbf{1 8 3 2}$ (по Кеппену) & $\mathbf{6 3}$ & & 383 \\
1837 & - & 428 & 579 \\
1846 - І вариант & 138 & 546 & $509 / 10$ дух. 3ван \\
1846 - ІІ вариант & 138 & $532 / 15$ дух. зван & $\mathbf{1 0 6 0}$ чел. обоего пола \\
1850 (по Кеппену) & 109 арнаутских & 541 & 573 \\
1880 - І вариант & - & $526 / 15$ дух. зван & $514 / 19$ дух. зван \\
1880 - ІІ вариант & 135 & 548 & 518 \\
1883 & 137 & 700 & 663 \\
1893 & 175 & & \\
\hline
\end{tabular}

* Примечание: через ( / ), дается кол-во человек духовного звания. Расположена в дополнение к первой цифре мужского и женского населения, так как отдельно отмечалось духовенство.

** Источник: Кеппен, П. И. Об этнографической карте европейской России, П. Кеппена, изданной императорским Русским географическим обществом, СПб. Тип. Академия Наук, 1852; Дерментли Ф. Перелистывая страницы памяти. Донецк. 2003. С. 28.

Приложение №1(a). График эволюции численности населения в албанской колонии Каракурт (1825 - 1893 гг.) (Подсчитано автором - И. Д.)

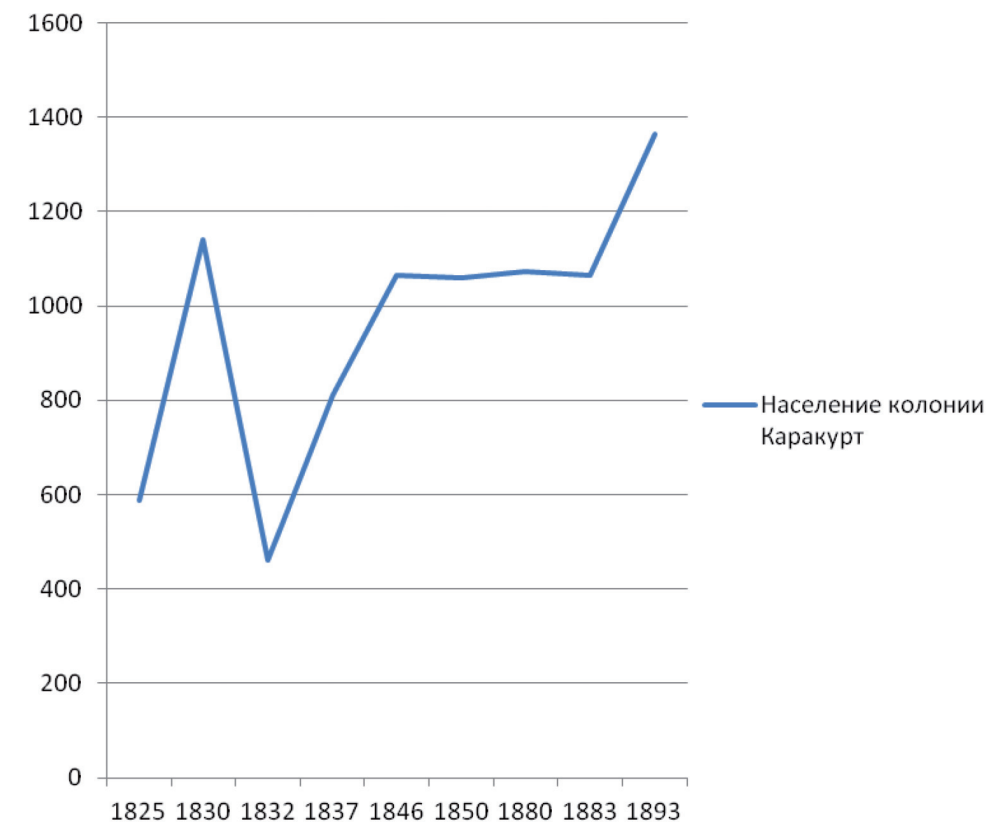


Приложение 2. Албанец (слева) и грек (справа). Первая половина XIX в.

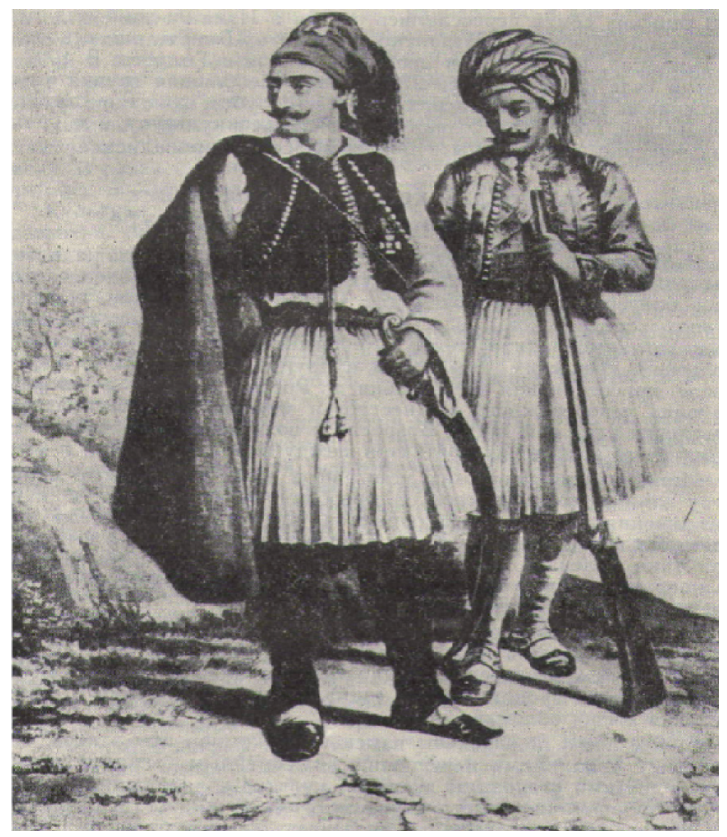

(По: Зеленчук В. С., Население Бессарабии и Поднестровья в ХІХ в, Кишинев, 1979).

\title{
THE PROBLEM OF THE RESETTLEMENT OF ALBANIANS TO BESSARABIA AT THE BEGINNING OF THE 19TH CENTURY
}

\begin{abstract}
Summary
The work is devoted to researching the evolution of the historiographical interpretations and assessments of the settlement process of the southern part of Bessarabia by Albanian colonists. The present paper aims at analyzing the late-date historiographical works and investigations of modern, inter-war, postwar and contemporary periods concerning the topic of the migration of Balkan refugees to the territory of Bessarabia in the beginning of the $19^{\text {th }}$ century. On the basis of the historiographical analysis, the following conclusions have been drawn: historiographical research has pointed out the distinct stages and tendencies concerning the aforementioned process. The revision of the sources from that period and the analysis of the contemporary sources give us a possibility to understand the controversies existing in the then historiographical interpretations of the colonization of Bessarabia at the beginning of the $19^{\text {th }}$ century.
\end{abstract}


In order to elucidate the investigated problem, two basic concepts have been traced out: one from the tsarist imperialist perspective (as in the case of the historiography before Pre-revolution and the Soviet period), and another one from the inter-war and contemporary Bulgarian and Romanian point view.

It is worth mentioning that, nowadays, we can only have limited historiographical visions in researching the mentioned problem, especially, the one concerning the Albanian colonization. The analysis of the sources and of the research on this subject reveals the scarcity of any specialized studies dealing with the mentioned problem. Moreover, certain important problems are not investigated. Hence, the need to investigate those issues and to find the new sources which would elucidate these problems. 
